\title{
IMPROVED COLLAGEN EXTRACTION BY MODIFIED LONGIN METHOD
}

\section{T A BROWN*, D E NELSON, J S VOGEL**, and J R SOUTHON** \\ Department of Archeology, Simon Fraser University Burnaby, BC V5A 1 S6 Canada}

ABSTRACT. A re-evaluation of the Longin collagen-extraction method shows that a lower reflux temperature reduces degradation of protein ("collagen") remnants. This allows additional purification through ultrafiltration to isolate the $>30 \mathrm{kDalton}$ fraction of the reflux product.

\section{INTRODUCTION}

The radiocarbon dating of bone has been problematic since the early days of ${ }^{14} \mathrm{C}$ dating due to frequent discord between bone and associated charcoal dates and/or between different fractions isolated from a single bone. Recently published studies show that such problems still exist (Gurfinkel, 1987; Mellars et al, 1987; Stafford et al, 1987) and suggest that they are due to difficulties in removing contaminants from the bone extracts used for dating.

Most methods of preparing bone for ${ }^{14} \mathrm{C}$ dating used today are designed to extract and purify (with varying amounts of success) some fraction of the organic remnants in the bone; in general, the stated goal of the methods is to isolate collagen (or the amino acids of collagen). Current evidence concerning the state of preservation of collagen molecules in fossil bone (eg, Tuross et al, 1980; Brown \& Nelson, ms in preparation) suggests that the term "collagen," with its rather specific molecular-biological definition, is not appropriate for the fraction which these methods attempt to isolate. In this paper we use "protein-remnants" for the peptides of interest in the fossil bone.

The commonly used Longin (1971) collagen-extraction method converts the protein-remnants to gelatin with the aim of eliminating humic substances and any other contaminants in the process. Unfortunately, it has become clear that this method is not always successful at eliminating such contaminants to the levels required for many dating applications (Gurfinkel, 1987; Stafford et al, 1987). We have re-examined the extraction conditions of the Longin method in the light of currently available information on the properties of modern bone and tissue collagen (eg, Piez \& Reddi, 1984). Based on our results, we suggest significant modifications to the Longin reflux conditions. These modifications maximize product yield while minimizing the degradation of the extracted protein-remnants, thereby, significantly improving the yield of larger peptides as compared to the Longin method. Since the contaminants are likely to be of relatively low molecular weight (eg, fulvic acids (Stevenson, 1982)), we propose an additional ultrafiltration step to extract only the larger peptides from the reflux

* Present address: Department of Geophysics AK-50, University of Washington, Seattle, Washington 98195

**Also at: Tandem Accelerator Laboratory, McMaster University, Hamilton, Ontario L8S 4K1, Canada 
solution. Finally, we present evidence that the product of the modified method is more suitable for ${ }^{14} \mathrm{C}$ dating.

\section{METHODS}

Three bones of different ages were used in this study; sample A: from a fully adult wolf $<200$ BP, sample B: from an 18-year-old female human $\sim 5000$ BP and sample C: from a bison $\sim 10,000$ BP. The first two samples were obtained as coarse powders $(\sim 1 \mathrm{~mm})$ from another study while the latter was an intact bone. Inspection of the samples indicated that they were well preserved, especially sample C, which had the appearance of a dried, fresh bone. We investigated the influence of reflux temperature and acid concentration on the yield and molecular weight (MW) distribution of products obtained from these bones.

Product yields were determined as functions of reflux temperature as follows. For each reflux temperature, five coarsely powdered subsamples weighing between 10 to $60 \mathrm{mg}$ were demineralized by repeated soaking overnight in $0.25 \mathrm{~N} \mathrm{HCl}$ and then refluxed in $0.1 \mathrm{~N} \mathrm{HCl}$ for $\sim 16 \mathrm{hr}$. The resulting solutions were filtered to remove insoluble residues, lyophilized and weighed to measure the product yield. In order to crudely determine their MW distributions, some of these products were dissolved in $0.01 \mathrm{~N}$ $\mathrm{HCl}$ and ultrafiltered. The ultrafiltration devices (Centricon 30 (or 10), Amicon Canada, Ltd) separated the products into greater-than and lessthan $30(10) \mathrm{kD}$ fractions which were then lyophilized and weighed (the Dalton unit is a measure of molecular weight; $1 \mathrm{kDalton}=1000 \mathrm{amu}$ ).

We also determined the MW distribution of the products as a function of the acid concentration of the reflux solution. Subsamples of demineralized and lyophilized sample $\mathrm{C}$ were refluxed for $\sim 16 \mathrm{hr}$ in solutions ranging from 0.01 to $0.25 \mathrm{~N} \mathrm{HCl}$. The resulting solutions were filtered, lyophilized and weighed. The MW distributions of these products were examined by sodium dodecyl sulfate-polyacrylamide gel electrophoresis (SDS-PAGE) using the discontinuous gel system developed by Laemmli (1970).

As a further test, several other bones (samples D through $\mathrm{H}$ ) were prepared following our modified Longin method (described below) and dated at the Simon Fraser University AMS facility. The dates were obtained following the procedures described by Nelson et al (1986).

\section{RESULTS AND DISCUSSION}

The product yields at reflux temperatures between $32-76^{\circ} \mathrm{C}$ are shown in Figure 1 . The product yield from sample $\mathrm{C}$ when refluxed at $90^{\circ} \mathrm{C}$ was 12 $\pm 2 \%$, essentially the same as all sample $\mathrm{C}$ yields at reflux temperature $\geq 48^{\circ} \mathrm{C}$. At temperatures $<\mathrm{ca} 48^{\circ} \mathrm{C}$, the reflux-insoluble residues were gelatinous lumps very similar in appearance to the demineralization residues before refluxing. At higher temperatures, the very small amounts of insoluble residue remaining after refluxing lost this appearance. The $\geq 58^{\circ} \mathrm{C}$ product yields are consistent with demineralization residue yields of $23 \%$, $18 \%$ and $16 \%$ for samples A, B, and C, respectively.

The product yields seen in Figure 1 are consistent with the observation that the fibril structure of mammalian collagen denatures at ca $58^{\circ} \mathrm{C}(\mathrm{eg}$, 


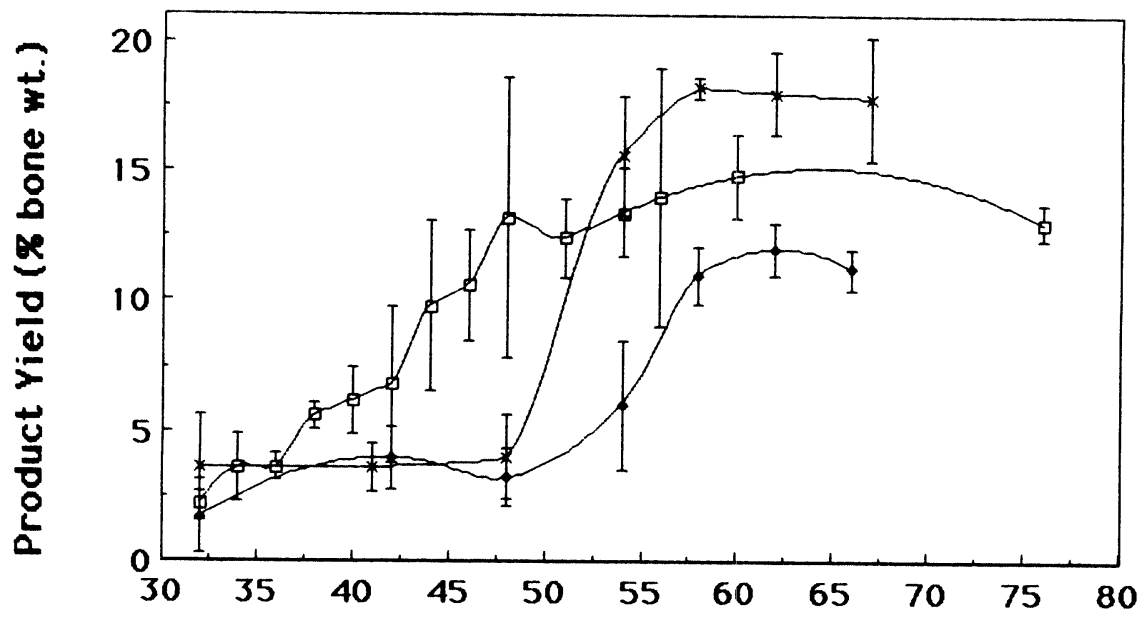

\section{Reflux Temperature $\left({ }^{\circ} \mathrm{C}\right)$}

Fig 1. Variation of product yield with reflux temperature for samples A (X), B ( $\downarrow)$ and $C(\square)$. The error bars represent the one standard deviation scatter in the five subsamples processed at each reflux temperature.

Piez, 1984). This implies that the original fibril structure of native collagen is relatively intact in the fossil bones in agreement with electronmicroscopy results obtained by many others (eg, Doberenz \& Wyckoff, 1967; Tuross $e t$ $a l, 1980)$. The increasing yield for all three samples as temperatures approach $58^{\circ} \mathrm{C}$ and the constancy of yield thereafter indicates that collagen solubilization during refluxing is initiated by the breakup of the fibril structure. The constancy of yield above $58^{\circ} \mathrm{C}$ shows that under these conditions refluxing at higher temperatures is unnecessary.

The greater-than and less-than $30 \mathrm{kD}$ or $10 \mathrm{kD}$ fractions of the products are given in Table 1 as a function of reflux temperature. The MW distribution of the sample A product changes noticeably with increasing temperature; the ratio of the fractions is constant at 0.75 below $58^{\circ} \mathrm{C}$, rises to 0.87 at $58^{\circ} \mathrm{C}$ and then drops dramatically to 0.24 and 0.13 at $62^{\circ} \mathrm{C}$ and $68^{\circ} \mathrm{C}$, respectively. The $>30 \mathrm{kD}$ fraction (as a percentage of initial bone weight) rises with temperature to a peak at $58^{\circ} \mathrm{C}$ and then, although the product yield remains constant, decreases with increasing temperature. These trends are also evident in the sample $\mathrm{B}$ data given in Table 1 (and in $30 \mathrm{kD}$ sample B and $10 \mathrm{kD}$ sample A data which are not reported here). Subsamples of $\mathrm{C}$ which had been refluxed at $90^{\circ} \mathrm{C}$ were found to have essentially no $>10 \mathrm{kD}$ fraction.

These data suggest that the $>30 \mathrm{kD}$ yield is dependent on two processes: solubilization of the protein-remnants through the denaturing of the fibril structure as discussed above, and temperature-dependent degradation of the solubilized protein-remnants. While the degradation reaction has not been identified conclusively, the SDS-PAGE information presented 
TABLE 1

Molecular weight distribution of product for several reflux temperatures

\begin{tabular}{|c|c|c|c|c|}
\hline $\begin{array}{l}\text { Reflux } \\
\text { temp } \\
\left({ }^{\circ} \mathrm{C}\right)\end{array}$ & $\begin{array}{l}\text { Initial } \\
\text { bone } \\
\text { wt } \\
(\mathrm{mg})\end{array}$ & $\begin{array}{c}\text { Reflux } \\
\text { product } \\
(\mathrm{mg}(\% \text { bone } w t))\end{array}$ & \multicolumn{2}{|c|}{$\begin{array}{l}\text { Ultrafiltration products } \\
\text { (mg (\% bone wt; } \\
\% \text { reflux product) })\end{array}$} \\
\hline \multicolumn{3}{|c|}{ Sample A } & $>30 \mathrm{kD}$ & $<30 \mathrm{kD}$ \\
\hline 48 & 40.2 & $2.1(5)$ & $0.9(2 ; 43)$ & $1.2(3 ; 57)$ \\
\hline 54 & 54.1 & $8.5(16)$ & $2.9(5 ; 34)$ & $3.8(7 ; 45)$ \\
\hline 58 & 45.1 & $8.2(18)$ & $3.2(7 ; 39)$ & $3.8(8 ; 46)$ \\
\hline 62 & 44.6 & $7.9(18)$ & $1.3(3 ; 16)$ & $5.2(12 ; 66)$ \\
\hline 67 & 45.9 & $8.6(19)$ & $0.8(2 ; 9)$ & $6.1(13 ; 71)$ \\
\hline \multicolumn{3}{|c|}{ Sample B } & $>10 \mathrm{kD}$ & $<10 \mathrm{kD}$ \\
\hline 48 & 60.1 & $1.3(2)$ & $0.5(1 ; 38)^{*}$ & $1.2(2 ; 92)^{*}$ \\
\hline 54 & 30.3 & $1.7(6)$ & $0.6(2 ; 35)^{*}$ & $1.5(5 ; 88) *$ \\
\hline 58 & 26.6 & $3.1(12)$ & $1.2(5 ; 39)$ & $1.7(6 ; 55)$ \\
\hline 62 & 38.6 & $5.1(13)$ & $1.4(4 ; 27)$ & $3.2(8 ; 63)$ \\
\hline
\end{tabular}

$*$ The $>100 \%$ totals of the $>$ and $<10 \mathrm{kD}$ fractions are attributed to the absorption of water by the very hygroscopic $<10 \mathrm{kD}$ fractions during weighing.

below suggests that acid-hydrolysis is responsible. These results show that the highest $>30 \mathrm{kD}$ yield is obtained at $58^{\circ} \mathrm{C}$ as a balance between maximizing solubilization and minimizing degradation of the protein-remnants.

The MW distribution of the sample $\mathrm{C}$ products as a function of the acid concentration of the reflux solution can be seen in Figure 2. It is clear that the degradation of solubilized protein-remnants increases with increasing acid concentration. The changes in the MW distributions are not related to product yield variations as the yield was $\sim 13 \%$ for all reflux acid concentrations studied. Refluxing in neutral $\mathrm{pH}$ solution was found to give a very low product yield presumably because of fibril stability under the non-acidic conditions.

The dependence of the MW distribution on the acid concentration suggests that acid-hydrolysis of the solubilized protein-remnants causes the degradation seen in Figure 2 and the temperature-dependent degradation discussed above. Clearly, the reduction of degradation by refluxing at lower acid concentrations will increase the $>30 \mathrm{kD}$ yield.

The lyophilized $>30 \mathrm{kI}$ products obtained from samples A, B, C and other well-preserved bones are white to light tan, essentially non-hygroscopic and have the appearance of fine-pore sponges. Greater-than $30 \mathrm{kD}$ products obtained from modern bone samples match this description except that they are invariably white. The $<30 \mathrm{kD}$ products from the fossil bones tend to be darker tan and more hygroscopic than their corresponding $>30 \mathrm{kD}$ products. In many cases, the $<30 \mathrm{kD}$ products were brown, very hygroscopic, and had the appearance of an amorphous scum, similar to typical products of the Longin method.

Based on the above results, we prepared several bones for ${ }^{14} \mathrm{C}$ dating by the following modified Longin method:

1) demineralize coarsely powdered bone by repeated soaking overnight in $0.25 \mathrm{~N} \mathrm{HCl}$, 
2) reflux demineralization residues in $0.01 \mathrm{~N} \mathrm{HCl}$ at $58^{\circ} \mathrm{C}$ for $\sim 16 \mathrm{~h}$ and then filter to remove reflux-insoluble residues,

3) ultrafilter reflux solution and lyophilize $>30 \mathrm{kD}$ fraction to obtain the final product.

The reflux conditions were chosen to maximize product yield while minimizing degradation of the product peptides. The ultrafiltration step was added to separate large quasi-intact protein fragments from smaller peptides and contaminants such as humic substances. The dates obtained for the greater-than and less-than fractions are given in Table 2.

The ${ }^{14} \mathrm{C}$ dates obtained for the $>30 \mathrm{kD}$ fractions are generally older than the corresponding $<30 \mathrm{kD}$ dates; the age difference being very pronounced for samples D and E, and of lesser significance for samples F, G, and $\mathrm{H}$. This implies that the ultrafiltration step has preferentially removed younger components of the product which probably were contaminants. These two fractions would have been mixed together in the normal Longin method. Thus, with the removal of contaminants by ultrafiltration, dating

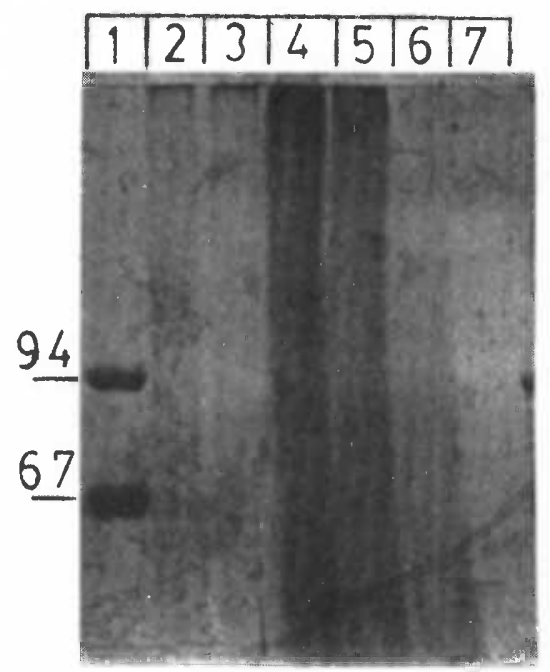

Fig 2. SDS-PAGE (8\% running gel) of reflux product obtained from various reflux solution acid concentrations. Lane 1 shows $94 \mathrm{kD}$ and $67 \mathrm{kD}$ protein standard bands which indicate that the gel shows proteins that range from $\sim 150$ to $\sim 50 \mathrm{kD}$ top to bottom. The remaining 6 lanes show the MW distributions of the reflux products as follows: lane 2-subsample not refluxed (demineralized only); very little of sample was small enough to enter running gel, lane $3-0.01 \mathrm{~N} \mathrm{HCl}$ reflux; very little of sample was small enough to enter running gel, lane $4-$ $0.025 \mathrm{~N} \mathrm{HCl}$; significant amount of sample was small enough to enter running gel and showed a continuous MW distribution, lane $5-0.05 \mathrm{~N} \mathrm{HCl}$; same as lane 4 except that there is more sample in the $\sim 100$ to $50 \mathrm{kD}$ range, lane $6-0.10 \mathrm{~N} \mathrm{HCl}$; all of sample is $\lesssim 100 \mathrm{kD}$ and significant amounts were probably small enough to have been lost off the bottom of the gel, lane $7-0.25 \mathrm{~N} \mathrm{HCl}$; all of sample was $\lesssim 50 \mathrm{kD}$. Approximately the same sample weight was loaded into each of lanes 2 to 7 . The mottled section on the lower left and the sloping line on the lower right are due to the mounting of the gel for photography. 
TABLE 2

Radiocarbon ages of molecular weight fractions

\begin{tabular}{|c|c|c|c|c|c|}
\hline \multirow[b]{2}{*}{ Sample } & \multirow{2}{*}{$\begin{array}{l}\text { Bone } \\
\text { wt(g), } \\
\text { color }\end{array}$} & \multirow{2}{*}{$\begin{array}{c}\text { Reflux } \\
\text { product } \\
(\mathbf{m g})\end{array}$} & \multicolumn{3}{|c|}{ Ultrafiltration products } \\
\hline & & & Fraction* & $\begin{array}{c}\text { Yield } \\
(\mathrm{mg}(\% \text { bone } \mathrm{wt}))\end{array}$ & $\begin{array}{l}{ }^{14} \mathrm{C} \text { age } \\
(\mathrm{ka} \text { BP) }\end{array}$ \\
\hline \multirow[t]{2}{*}{$\mathbf{D}$} & 0.7419 & 33.0 & $>30 \mathrm{kD}$ & $16.3(2.2)$ & $40.7 \pm 1.1$ \\
\hline & White & & $<30 \mathrm{kD}$ & $16.7(2.3)$ & $32.4 \pm 0.5$ \\
\hline \multirow[t]{2}{*}{$\mathbf{E}$} & 0.3588 & 22.4 & $>30 \mathrm{kD}$ & $15.0(4.1)$ & $44.6 \pm 1.6-1.9$ \\
\hline & Brown & & $<30 \mathrm{kD}$ & $9.4(2.6)$ & $37.2 \pm 0.7$ \\
\hline \multirow[t]{2}{*}{$\mathbf{F}$} & 0.5666 & 18.5 & $>30 \mathrm{kD}$ & $5.8(1.0)$ & $34.1 \pm 0.5$ \\
\hline & Brown & & $<30 \mathrm{kD}$ & $12.7(2.2)$ & $32.2 \pm 0.5$ \\
\hline \multirow[t]{2}{*}{ G } & 0.3848 & 21.1 & $>30 \mathrm{kD}$ & $5.9(1.5)$ & $39.9+1.4-1.7$ \\
\hline & Tan & & $<30 \mathrm{kD}$ & $15.2(4.0)$ & $37.9 \pm 0.8$ \\
\hline \multirow[t]{2}{*}{$\mathbf{H}$} & - & 37.9 & $>30 \mathrm{kD}$ & $14.6(39)^{* * *}$ & $16.20 \pm 0.15$ \\
\hline & Gray & & $<30 \mathrm{kD}$ & $23.3(61)^{* *}$ & $16.7 \pm 0.2$ \\
\hline
\end{tabular}

* For each of the samples, an indication of the degree of collagen preservation can be obtained from the total product obtained (the sum of the $<$ and $>30 \mathrm{kD}$ fractions) as compared to the collagen content of modern bone $(\sim 0.20)$. This gives preservations of $75 \%, 22 \%$, $34 \%, 16 \%$, and $28 \%$ for samples $A$ and $D$ through $G$, respectively. sured.

** Expressed as percentage of reflux product since the initial bone wt was not mea-

of the $>30 \mathrm{kD}$ fraction is likely to provide more reliable ${ }^{14} \mathrm{C}$ dates on bone than the traditional Longin product.

\section{CONCLUSION}

We suggest modification of the Longin collagen-extraction method on the basis of a re-evaluation of the reflux conditions and examination of the products produced under varied extraction conditions. The modifications involve refluxing in a weak acid solution $(0.01 \mathrm{~N} \mathrm{HCl})$ at lower temperature $\left(58^{\circ} \mathrm{C}\right)$ followed by ultrafiltration to isolate the $>30 \mathrm{kD}$ fraction of the reflux product. Radiocarbon dating of the $>30 \mathrm{kD}$ and $<30 \mathrm{kD}$ fractions from several bones indicates that the ultrafiltration step removes some contaminants normally left in the Longin product. In addition, the product of this modified method is non-hygroscopic, and hence, is considerably easier to handle than the normal Longin product. Thus, the modifications improve the Longin method and the $>30 \mathrm{kD}$ fraction is likely to provide more reliable dates than the traditional Longin method.

\section{ACKNOWLEDGMENTS}

We thank Brian Chisholm (SFU) for supplying samples, John Curran, Barry Honda, and John Webster (SFU) for use of their facilities and their advice, $\mathrm{H}$ Roman (McMaster) for help with the ${ }^{14} \mathrm{C}$ measurements, Pieter Grootes (UW) for his comments, and the staff of the McMaster University Tandem Accelerator Laboratory for their assistance and the use of their accelerator. Funding was provided by NSERC of Canada, and by Simon Fraser and McMaster Universities. 


\section{REFERENCES} Doberenz, A R and Wyckoff, R W, 1967, Fine structure of fossil collagen: Nat Acad Sci Proc,
v 57, p 539-541.

Gurfinkel, D M, 1987, Comparative study of the radiocarbon dating of different bone collagen preparations: Radiocarbon, v 29, no. 1, p 45-52.

Laemmli, U K, 1970 , Cleavage of structural proteins during the assembly of the head of Bacteriophage T4: Nature, v 227, p 680-685.

Longin, R, 1971, New method of collagen extraction for radiocarbon dating: Nature, v 230, p 241-242.

Mellars, P A, Bricker, H M, Gowlett, J A J and Hedges, R E M, 1987, Radiocarbon accelerator dating of French Upper Palaeolithic sites: Current Anthropology, v 28, no. 1, p 128 133.

Nelson, D E, Vogel, J S, Southon, J R and Brown, T A, 1986, Accelerator radiocarbon dating at SFU, in Stuiver, $M$ and Kra, R S, eds, Internatl ${ }^{14} \mathrm{C}$ conf, 12 th, Proc: Radiocarbon, v 28,
no. $2 \mathrm{~A}, \mathrm{p} 215-222$.

Piez, K A, 1984, Molecular and aggregate structures of the collagens, in Piez, K A and Reddi, A H, eds, Extracellular matrix biochemistry: New York, Elsevier, p 1-39.

Piez, K A and Reddi, A H, eds, 1984, Extracellular matrix biochemistry: New York, Elsevier, 473 p.

Stafford, T W, Jr, Jull, A J T, Brendel, K, Duhamel, R C and Donahue, D, 1987, Study of bone radiocarbon dating accuracy at the University of Arizona NSF Accelerator Facility for Radioisotope Analysis: Radiocarbon, v 29, no. 1, p 24-44.

Stevenson, F J, 1982, Humus chemistry; genesis, composition, reactions: New York, WileyInterscience, $443 \mathrm{p}$.

Tuross, N, Eyre, D R, Holtrop, M E, Glimcher, M J and Hare, P E, 1980, Collagen in fossil bones, in Hare, P E, Hoering, T C and King, K, Jr, eds, Biogeochemistry of amino acids: New York, John Wiley \& Sons, p 53-63. 